\title{
TINDAK TUTUR DALAM PROSES JUAL BELI DI PASAR TRADISIONAL SURAKARTA
}

\author{
Ririn Linda Tunggal Sari, Sumarlam, Dwi Purnanto \\ Megister Linguistik Deskriptif Pascasarjana Universitas Sebelas Maret \\ rye2_12@yahoo.co.id
}

\begin{abstract}
Background: The objectives of this research are: to describe the forms of speech acts and to show the most dominant speech act and the reasons of its use; and to describe and define the politeness principle found in the the goods sale and purchase process at traditional markets in Surakarta.

Method: This research used the descriptive qualitive method with the pragmatics approach. Its sources were conversations or dialogues. The data of the research were utterances and their contexts which contain speech acts and which apply the cooperative principle in the goods sale and purchase process at traditional markets in Surakarta, namely: Pasar Gedhe market, Pasar Klewer market, Pasar Ledoksari market, Pasar Nusukan market, and Pasar Mojosongo market. The collection of the data used the listening method. The data were collected through tapping, uninvolved conversation observation, recording technique, and note-taking techniques. They were analyzed by using the means-end techique. The result of the analysis was presented with informal and formal methods.

Result: There are five types of speech act employed by the sellers and the buyers to express their intentions, namely: utterances, (b) verdictive utterances, (c) directive utterances, (d) commissive utterances, and phatic utterances. The most dominant speech act used in the goods sale and purchase process at traditional markets in Surakarta is commisive utterances as indicated by 88 data. In relation to the cooperative principle, in the goods sale and purchase process at traditional markets in Surakarta some speech acts adhere to the cooperative principle, but some violate it. The adherence to and violence of the cooperative principle are balanced in term of frequency i.e. 95 data for each. The latter is due to the intentions of the sellers and the buyers to show their politeness.

Conclusion: there are applications of the speech act theory, the cooperative principle, and the politeness in the dialogues between the sellers and the buyers in the the goods sale and purchase process at traditional markets in Surakarta
\end{abstract}

Keywords: Speech act, cooperative principle, sale and purchase process, pragmatics 


\begin{abstract}
ABSTRAK
Latar Belakang: Tujuan penelitian ini adalah mendeskripsikan bentuk tindak tutur dan menunjukkan tindak tutur yang dominan berserta alasannya, serta mendeskripsikan dan menjelaskan prinsip kerjasama dan prinsip kesantunan yang terdapat dalam proses jual beli barang di pasar tradisional Surakarta.

Metode: Penelitian ini termasuk jenis penelitian kualitatif dengan pendekatan pragmatik. Sumber data penelitian ini adalah percakapan atau dialog dalam proses jual beli di pasar tradisional Surakarta, sedangkan datanya adalah tuturan beserta konteksnya yang mengandung tindak tutur dan menerapkan prinsip kerja sama dalam proses jual beli di pasar tradisional Surakarta, seperti pasar Gedhe, Klewer, Ledoksari, Nusukan, Mojosongo. Metode pengumpulan data yang digunakan adalah metode simak, sedangkan teknik untuk pengumpulan data menggunakan teknik simak libat cakap (SLC), teknik rekam, dan teknik catat. Teknik analisis datanya dengan menggunakan teknik analisis means-end. Metode penyajian hasil analisis data dalam penelitian ini adalah penyajian secara informal dan formal.

Hasil: Dalam penelitian ini ditemukan 5 jenis tindak tutur yang digunakan oleh penjual ataupun pembeli dalam mengutarakan maksudnya. Tindak tutur tersebut meliputi tindak tutur a) asertif (assertif utterances), b) verdiktif (verdictive utterances), c) direktif (directive utterances), d) komisif (commissive utterances), e) fatis (phatic utterances). Tindak tutur yang paling banyak ditemukan dalam proses jual beli di pasar tradisional di Surakarta, adalah tindak tutur komisif, ditunjukkan dengan 88 data. Berkaitan dengan prinsip kerja sama, dalam penelitian ini ditemukan tindak tutur yang mematuhi dan melanggar prinsip kerja sama. Pematuhan dan pelanggaran prinsip kerja samanya menunjukkan keseimbangan, yakni ditunjukan dengan 95 data berupa pematuhan dan 95 data berupa pelanggaran prinsip kerja sama dari 190 data. Pelanggaran terhadap prinsip kerja sama tersebut, disebabkan karena penjual atau pembeli bermaksud menunjukkan kesantunan.
\end{abstract}

Kesimpulan: terdapat penerapan teori tindak tutur, prinsip kerjasama dan kesantunan dalam dialog antara penjual dan pembeli pada proses jual beli di pasar tradisional Surakarta.

Kata Kunci: tindak tutur, prinsip kerja sama, proses jual beli, pragmatik

\title{
PENDAHULUAN
}

Komunikasi merupakan kegiatan sosial yang dapat terjadi di mana saja, misalnya di rumah, di kantor, di rumah makan, di pasar dan lain sebagainya. Pasar merupakan salah satu tempat bertemunya penjual dan pembeli, yang melibatkan keduanya dalam proses jual dan beli. Penjual dan pembeli dituntut untuk selalu melakukan komunikasi yang baik dalam proses jual beli tersebut. Pada saat berlangsungnya proses jual beli antara penjual dan pembeli, banyak ditemukan tuturan- 
tuturan dari penjual ataupun pembeli yang menerapankan teori tindak tutur dan prinsip kerjasama. Tuturan-tuturan itulah yang menurut peneliti menarik untuk diteliti. Beragamnya penjual dan pembeli yang terdapat di pasar tradisional akan memunculkan tuturan dan variasi bahasa yang beragam pula. Tuturan yang muncul pada proses jual beli juga memiliki fungsi yang beragam pula, ada yang berfungsi untuk menunjukan, menjelaskan, menyebutkan, meminta, menganjurkan, menawarkan, menolak, menyetujui, berterima kasih, dan lain sebagainya.

Penelitian ini bertujuan untuk (1) mendeskripsikan jenis-jenis tindak tutur yang terdapat dalam proses jual beli di pasar tradisional Surakarta, dan menunjukkan tindak tutur yang dominan berserta alasan yang menyebabkan tindak tutur tersebut dominan dalam proses jual beli barang di pasar tradisional Surakarta, dan (2) mendeskripsikan dan menjelaskan prinsip kerjasama dan prinsip kesantunan yang dimunculkan oleh penjual ataupun dalam proses jual beli barang di pasar tradisional Surakarta.

Penelitian ini merupakan suatu penerapan kajian pragmatik pada dialog secara langsung, yang fokus pada penerapan tindak tutur menurut Kreidler dalam proses jual beli. Kreidler (1998:183-194) dalam bukunya Introducing English Semantics membagi tindak tutur menjadi tujuh bagian, yaitu:

\section{a. Asertif (Assertif Utterances)}

Tindak tutur asertif adalah tindak tutur yang terjadi ketika pembicara dan pendengar menggunakan bahasa untuk menceritakan apa yang mereka ketahui dan percayai yang sesuai dengan fakta, misalnya mengatakan (allege), mengumumkan (announce), menyetujui (agree), melaporkan (report), menjelaskan (explain) mengingatkan (remind), menyanggah (protest). 


\section{b. Performatif (Performative Utterances)}

Tindak tutur performatif adalah tindak tutur yang membuat atau menyebabkan resminya apa yang diucapkan, misalnya mengumumkan (declared), membaptis (baptize), menyebut atau menamakan (name), mencalonkan (nominate),menjatuhkan hukuman (pronounce).

c. Verdiktif (Verdictive Utterances)

Tindak tutur verdiktif terjadi karena penutur membuat penilaian terhadap tindakan orang lain, biasanya mitra tutur, misalnya menuduh atau menyalahkan (accuse), tuntutan atau tuduhan (charge), pernyataan menyesal (excuse) berterima kasih (thanx).

\section{d. Ekspresif (Expressive Utterances)}

Tindak tutur ekspresif terjadi karena tindakan penutur, kegagalan penutur serta akibat yang ditimbulkan kegagalan itu, misalnya mengakui (acknowledge, admit, confess), mengingkari (deny), minta maaf (apologize).

\section{e. Direktif (Directive Utterances)}

Tindak tutur direktif mengandung maksud bahwa penutur meminta mitra tutur untuk melakukan perbuatan atau tidak melakukan perbuatan. Tindak tutur direktif terbagi menjadi tiga macam, yaitu perintah (commands), permintaan (request), dan anjuran (suggestions).

\section{f. Komisif (Commissive Utterances)}

Tindak tutur komisif merupakan tindak tutur yang mengikat seorang penutur untuk melakukan suatu tindakan, misalnya menyetujui (agree), bertanya (ask), menawarkan (offer), menolak (refuse), berjanji atau bersumpah (swear). 


\section{g. Fatis (Phatic Utterances)}

Tindak tutur fatis merupakan tindak tutur yang bertujuan untuk menciptakan hubungan antara penutur dan mitra tutur (Kreidler, 1998:194). Tindak tutur fatis meliputi ucapan salam, ucapan salam berpisah, cara-cara yang sopan seperti thank you, you are welcome, excuse me, yang tidak berfungsi verdiktif (penilaian terhadap tindakan orang lain) atau ekspresif (tindak akibat kegagalan penutur).

Satu hal yang sangat mendasar dari penggolongan tindak tutur ilokusi ke dalam bentuk tuturan menurut beberapa tokoh bahasa adalah tindak tutur ilokusi ternyata dapat memiliki bentuk-bentuk tuturan yang mencerminkan maksud dan fungsi komunikasi yang bermacam-macam. Dua jenis fungsi yang berbeda antara tokoh yang satu dengan tokoh yang lain dapat bertujuan untuk menyampaikan maksud yang sama, misalnya tindak tutur verdiktif dari Austin dan Kreidler, dan perfomatif dari Kreidler sama fungsi atau maksudnya dengan tindak tutur deklaratif menurut pengelompokan dari Searle dan Leech.

Perbedaan dan persamaan antara penamaan istilah dan fungsi tindak tutur dari Austin (1962:150-163), Searle (dalam Martinich (ed), 1996a:147-149, Asim Gunarwan, 1994:85-86), Leech (dalam M. D. D. Oka, 1993:327-329), dan Kreidler(1998:183-194), secara lebih lengkapnya dapat dilihat pada tabel berikut.

Tabel 1: Tindak Tutur menurut Austin, Searle, Leech, Kreidler

\begin{tabular}{|c|l|l|l|l|}
\hline No & \multicolumn{1}{|c|}{ Austin } & \multicolumn{1}{c|}{ Searle } & \multicolumn{1}{c|}{ Leech } & \multicolumn{1}{c|}{ Kreidler } \\
\hline 1 & Verdiktif & Deklarasi & Deklaratif & Verdiktif, Performatif \\
\hline 2 & Eksersitif & Direktif & Direktif & Direktif \\
\hline 3 & Komisif & Komisif & Komisif & Komisif \\
\hline 4 & Behabitif & Ekspresif & Ekspresif & Ekpresif \\
\hline
\end{tabular}




\begin{tabular}{|l|l|l|l|l|}
\hline 5 & Ekspositif & Asertif & Asertif & Asertif \\
\hline 6 & - & - & Rogatif & Fatis \\
\hline
\end{tabular}

\section{METODE PENELITIAN}

Penelitian ini termasuk jenis penelitian kualitatif yang bersifat deskriptif. Pendekatan yang digunakan dalam penelitian ini adalah pendekatan pragmatik.

Sumber data penelitian ini adalah percakapan atau dialog dalam proses jual beli barang di pasar tradisional Surakarta. Data dalam penelitian ini adalah tuturan yang mengandung tindak tutur dan menerapkan prinsip kerja sama beserta konteksnya dalam proses jual beli barang di pasar tradisional Surakarta, seperti pasar Gedhe, Klewer, Ledoksari, Nusukan, Mojosongo. Data tersebut diambil pada bulan November tahun 2012 sampai dengan Maret 2013.

Metode pengumpulan data yang digunakan untuk penelitian ini adalah metode simak. Pada praktiknya metode simak diwujudkan dengan teknik dasar dan teknik lanjutan. Adapun teknik dasar dari metode simak yang digunakan dalam penelitian ini adalah teknik sadap. Teknik lanjutan dalam penelitian ini dilakukan setelah teknik dasar. Teknik lanjutan yang digunakan dalam penyediaan data pada penelitian ini berupa teknik simak libat cakap (SLC), teknik rekam, dan teknik catat. Teknik analisis data dalam penelitian ini menggunakan teknik analisis means-end. Metode penyajian hasil analisis data dalam penelitian ini adalah penyajian secara informal dan formal.

\section{HASIL TEMUAN}

Adapun hasil temuan jenis-jenis tindak tutur dalam tuturan proses jual beli di pasar tradisional Surakarta, secara lebih lengkapnya dapat dilihat pada tabel berikut. 
Tabel 2: Tindak Tutur

\begin{tabular}{|c|c|c|c|}
\hline No & Jenis Tindak Tutur & Nomor Data & Jumlah \\
\hline 1 & $\begin{array}{l}\text { b. persetujuan } \\
\text { c. penawaran, } \\
\text { d. penolakan }\end{array}$ & $\begin{array}{l}3,4,5,8,9,16,17,25,28,32,36,42,43,44, \\
47,55,56,59,60,61,68,74,78,81,83,86,90, \\
92,94,100,102,106,108,110,114,115,117, \\
118,124,127,128,131,132,133,135,137, \\
141,144,147,148,149,153,157,159,162, \\
166,167,168,170,172,176,178,181,183,185 \\
187 \\
19,20,23,29,54,88,123,125,139,142,151, \\
154,180,184 \\
41,87,89,97,126,143,152,155\end{array}$ & $\begin{array}{l}1 \text { data } \\
14 \text { data } \\
8 \text { data }\end{array}$ \\
\hline 2 & $\begin{array}{l}\text { Tindak Tutur Asertif } \\
\text { a. mengatakan, } \\
\text { b. menyebutkan } \\
\text { c. menjelaskan, } \\
\text { d. menunjukkan, }\end{array}$ & $\begin{array}{l}7,13,18,22,26,37,45,51,53,62,63,65,69, \\
72,84,91,104,111,138,164,177,179,182 \\
64 \\
33,40,50,67,70,73,79,82,93,103,105,112, \\
119,120,129,136,145,146,150,165,169,173 \\
116,134,174\end{array}$ & $\begin{array}{l}49 \text { data } \\
23 \text { data } \\
1 \text { data } \\
22 \text { data } \\
3 \text { data }\end{array}$ \\
\hline 3 & Tindak Tutur Performatif & $-\mathrm{Cl}_{-}$ & - \\
\hline 4 & Tindak Tutur Verdiktif & $71,98,130,160,189,190$ & 6 data \\
\hline 5 & Tindak Tutur Ekspresif & - & - \\
\hline 6 & $\begin{array}{l}\text { Tindak Tutur Direktif } \\
\text { a. perintah } \\
\text { b. permintaan } \\
\text { c. anjuran }\end{array}$ & $\begin{array}{l}21,30,58,76,101 \\
1,6,11,12,14,15,24,27,31,35,38,39,46, \\
49,52,57,66,80,85,95,109,113,121,122, \\
156,158,188 \\
2,10,34,96,107,140,163,171,186\end{array}$ & $\begin{array}{l}41 \text { data } \\
5 \text { data } \\
27 \text { data } \\
9 \text { data }\end{array}$ \\
\hline 7 & $\begin{array}{l}\text { Tindak tutur fatis } \\
\text { Jumlah keseluruhan }\end{array}$ & $48,75,77,99,161,175$ & $\begin{array}{c}6 \text { data } \\
190 \text { data }\end{array}$ \\
\hline
\end{tabular}

Adapun tuturan-tuturan yang menunjukkan pematuhan dan pelanggaran prinsip kerja sama yang terdapat pada proses jual beli di pasar tradisional Surakarta, secara lebih lengkapnya dapat dilihat pada tabel berikut. 
Tabel 3: Pematuhan dan Pelanggaran Prinsip Kerja sama

\begin{tabular}{|c|c|c|c|c|c|}
\hline No & Prinsip Kerja sama & $\begin{array}{c}\text { No. Data Pematuh- } \\
\text { an }\end{array}$ & Jml & $\begin{array}{c}\text { No. Data Pelanggar } \\
\text {-an }\end{array}$ & jml \\
\hline 1 & $\begin{array}{l}\text { Maksim Kuantitas } \\
\text { (The Maxim of Quantity) }\end{array}$ & $\begin{array}{l}1,4,7,14,15,16, \\
17,22,25,30,35, \\
36,42,47,51,52, \\
54,59,60,61,63, \\
65,66,68,71,73, \\
74,75,76,77,85, \\
90,92,96,99,100, \\
101,102,106,114, \\
117,121,127,132, \\
159,160,189,190,\end{array}$ & 48 data & $\begin{array}{l}6,8,9,10,12,19, \\
23,24,27,28,29, \\
33,34,37,38,39, \\
41,43,44,46,50, \\
57,58,67,80,82, \\
87,89,113,119, \\
124,131,139,146, \\
149,153,157,166, \\
169,171,173,174, \\
176,180,182,\end{array}$ & 45 data \\
\hline 2 & $\begin{array}{l}\text { Maksim Kualitas } \\
\text { (The Maxim of Quality) }\end{array}$ & $72,134,165$ & 3 data & - & - \\
\hline 3 & $\begin{array}{l}\text { Maksim Relevansi } \\
\text { (The Maxim of Relevance) }\end{array}$ & $\begin{array}{l}5,13,18,26,40,45, \\
48,49,53,55,56, \\
79,84,91,95,97, \\
98,103,105,107, \\
109,111,116,122, \\
125,126,130,133, \\
135,136,138,141, \\
143,145,147,150, \\
152,154,155,156, \\
161,187,188,\end{array}$ & 43 data & $\begin{array}{l}62,128,140,163, \\
175,179,\end{array}$ & 6 data \\
\hline 4 & $\begin{array}{l}\text { Maksim Pelaksanaan } \\
\text { (The Maxim of Manner) }\end{array}$ & 64 & 1 data & $\begin{array}{l}2,3,11,20,21,31, \\
32,69,70,78,81, \\
83,86,88,93,94, \\
104,108,110,112, \\
115,118,120,123, \\
129,137,142,144, \\
148,151,158,162, \\
164,167,168,170, \\
172,177,178,181, \\
183,184,185,186,\end{array}$ & 44 data \\
\hline & Jumlah total & Pematuh-an & 95 data & Pelanggar-an & 95 data \\
\hline
\end{tabular}

\section{PEMBAHASAN}

\section{Penerapan Tindak Tutur dan Tindak Tutur yang Dominan dalam Proses Jual}

\section{Beli Barang di Pasar Tradisional Surakarta}

Pada hasil penelitian tentang penerapan tindak tutur yang terdapat dalam proses jual beli di pasar tradisional Surakarta sesuai dengan teori tindak tutur yang dikemukakan oleh Kreidler seperti dalam bukunya yang berjudul Introducing English 
Semantics (1998). Kreidler (1998:183-194) membagi tindak tutur menjadi tujuh kelompok, yaitu: a) asertif (assertif utterances), b) performatif (performative utterances), c) verdiktif (verdictive utterances),d) ekspresif (expressive utterances), e) direktif (directive utterances), f) komisif (commissive utterances), g) fatis (phatic utterances).

Temuan penelitian mengenai tindak tutur yang terdapat dalam proses jual beli di pasar tradisional Surakarta ternyata sesuai dengan teori tersebut. Dalam penelitian tindak tutur dalam proses jual beli di pasar tradisional Surakarta ditemukan 5 jenis tindak tutur yang menerapkan teori tindak tutur menurut Kreidler. Tindak tutur tersebut meliputi tidak tutur a) asertif (assertif utterances), b) verdiktif (verdictive utterances), c) direktif (directive utterances), d) komisif (commissive utterances), e) fatis (phatic utterances). Pemaparan mengenai penerapan teori tindak tutur yang terdapat pada proses jual beli di pasar tradisional Surakarta, sebagai berikut.

a) Tindak tutur asertif (assertif utterances) sebanyak 49 data, terbagi menjadi 4, yaitu tindak tutur asertif 'mengatakan' sebanyak 23 data, tindak tutur asertif ‘menjelaskan' sebanyak 22 data, tindak tutur asertif 'menunjukan' sebanyak 3 data, tindak tutur asertif 'menyebutkan' sebanyak 1 data.

b) Tindak tutur verdiktif (verdictive utterances) sebanyak 6 data.

c) Tindak tutur direktif (directive utterances) sebanyak 41data, terbagi menjadi 3, yaitu tindak tutur direktif 'perintah' sebanyak 4 data, tindak tutur direktif ‘permintaan' sebanyak 27 data, tindak tutur direktif ‘anjuran' sebanyak 10 data.

d) Tindak tutur komisif (commissive utterances) sebanyak 88 data, terbagi menjadi 4, yaitu tindak tutur komisif 'pertanyaan' sebanyak 65 data, tindak tutur komisif 
'persetujuan' sebanyak 1 data, tindak tutur komisif 'penawaran' sebanyak 14 data, tindak tutur komisif 'penolakan' sebanyak 8 data.

e) Tindak tutur fatis (phatic utterances) sebanyak 6 data.

Penjelasan mengenai jenis-jenis tindak tutur di atas menunjukan bahwa dari lima jenis tindak tutur yang terdapat dalam proses jual beli di pasar tradisional di Surakarta, tindak tutur yang paling banyak ditemukan adalah tindak tutur komisif, ditunjukkan dengan 88 data. Alasan banyak ditemukannya tindak tutur komisif dalam proses jual beli di pasar tradisional Surakarta, disebabkan banyak muncul tuturan dari penjual atau pembeli yang bermaksud sebagai pertanyaan ataupun penawaran atas suatu barang dagangan. Pada dasarnya di pasar tradisional banyak ditemukan bermacam-macam barang dagangan, dan seseorang pergi ke pasar tradisional untuk memperoleh barang yang diinginkannya dengan harga yang murah, untuk itu pembeli harus melakukan 'pertanyaan' dan 'penawaran', oleh sebab itulah tuturan yang bermaksud sebagai 'pertanyaan' dan 'penawaran' banyak ditemukan dalam proses jual beli di pasar tradisional.

\section{Penerapan Prinsip Kerja sama dan Prinsip Kesantunan dalam Proses Jual}

\section{Beli Barang di Pasar Tradisional Surakarta}

Pembahasan mengenai prinsip kerja sama dan prinsip kesantunan yang terdapat dalam proses jual beli barang di pasar tradisional Surakarta ini sesuai dengan teori prinsip kerja sama yang dikemukakan oleh Grice (1975:159) yaitu meliputi empat maksim, yaitu a) maksim kuantitas ( the maxim of quantity), b) maksim kualitas (the

maxim of quality), c) maksim relevansi ( the maxim of relevance), d) maksim pelaksanaan (the maxim of manner). 
Berkaitan dengan prinsip kerja sama, temuan dalam penelitian ini menunjukkan bahwa tindak tutur yang terdapat dalam proses jual beli barang di pasar tradisional Surakarta ada yang mematuhi prinsip kerja sama dan ada pula yang melanggarnya. Pematuhan dan pelanggaran prinsip kerja sama dalam proses jual beli barang di pasar tradisional Surakarta menunjukkan keseimbangan, yang ditunjukan dengan 95 data berupa bentuk pematuhan prinsip kerja sama dan 95 data berupa bentuk pelanggaran prinsip kerja sama dari 190 data. Keseimbangan antara jumlah tuturan yang menerapkan pematuhan dan pelanggaran prisip kerja sama dalam penelitian ini menunjukan bahwa, tuturan penjual atau pembeli pada proses jual beli di pasar tradisional Surakarta tidak selalu mematuhi prinsip kerja sama, ada kalanya penjual ataupun pembeli melanggar suatu prinsip kerja sama.

a. Pematuhan prinsip kerja sama yang terdapat dalam proses jual beli barang di pasar tradisional Surakarta meliputi pematuhan maksim kuantitas sebanyak 48 data, pematuhan maksim kualitas sebanyak 3 data, pematuhan maksim relevansi (hubungan) sebanyak 43 data, dan pematuhan maksim cara (pelaksanaan) sebanyak 1 data. Pematuhan prinsip kerja sama terdapat dalam penelitian ini didominasi oleh pematuhan terhadap maksim kuantitas, hal tersebut menunjukan bahwa penjual atau pembeli di pasar tradisional selalu berusaha untuk menuturkan tuturan secara jelas dan teratur, sehingga lawan tuturnya dapat memahami maksud yang terkandung dalam tuturan yang diucapkannya dan komunikasi dapat berlangsung dengan baik.

b. Pelanggaran prinsip kerja sama dalam proses jual beli barang di pasar tradisional Surakarta meliputi pelanggaran maksim kuantitas sebanyak 45 data, pelanggaran maksim relevansi (hubungan) sebanyak 6 data, dan pelanggaran maksim cara 
(pelaksanaan) sebanyak 44 data. Pelanggaran prinsip kerja sama yang terjadi dalam proses jual beli barang di pasar tradisional Surakarta didominasi oleh pelanggaran terhadap maksim kuantitas, hal ini terjadi karena cara bertutur yang tidak secara langsung dan berkepanjangan. Pelanggaran-pelanggaran terhadap prinsip kerja sama yang terdapat dalam proses jual beli barang di pasar tradisional Surakarta, disebabkan karena penjual atau pembeli bermaksud menunjukkan kesantunan dalam tuturannya supaya tidak menyinggung lawan tuturnya.

Masyarakat dan budaya Indonesia, khususnya di dalam kultur masyarakat Jawa, justru ada indikasi bahwa semakin panjang sebuah tuturan akan semakin sopanlah tuturan tersebut. Sebaliknya semakin pendek sebuah tuturan, akan semakin tidak sopanlah tuturan tersebut. Dengan demikian, dapat dikatakan bahwa untuk menunjukkan maksud kesantunan, suatu tuturan dalam hal tertentu dapat melanggar dan tidak mematuhi Prinsip Kerja Sama Grice.

\section{SIMPULAN DAN SARAN}

Dari pembahasan yang telah dihandirkan di atas dapat disimpulkan bahwa tindak tutur yang terdapat dalam proses jual beli di pasar tradisional Surakarta, ada 5 jenis tindak tutur. Tindak tutur tersebut meliputi tidak tutur a) asertif (assertif utterances), b) verdiktif (verdictive utterances), c) direktif (directive utterances), d) komisif (commissive utterances), e) fatis (phatic utterances). Tindak tutur yang paling mendominasi dalam proses jual beli di pasar tradisional Surakarta adalah tindak tutur komisif ditunjukan dengan 88 data yang menerapkan tindak tutur tersebut, terbagi

menjadi 4, yaitu tindak tutur komisif 'pertanyaan' sebanyak 65 data, tindak tutur 
komisif 'persetujuan' sebanyak 1 data, tindak tutur komisif 'penawaran' sebanyak 14 data, tindak tutur komisif 'penolakan' sebanyak 8 data.

Berkaitan dengan prinsip kerja sama, tindak tutur yang terdapat dalam proses jual beli barang di pasar tradisional Surakarta ada yang mematuhi prinsip kerja sama dan ada pula yang melanggarnya. Pematuhan dan pelanggaran prinsip kerja sama dalam proses jual beli barang di pasar tradisional Surakarta menunjukkan keseimbangan, yang berarti bahwa penjual dan pembeli dalam keseluruhan percakapan tidak selalu mematuhi atau melanggar prinsip kerja sama. Pematuhan prinsip kerja sama tersebut meliputi pematuhan maksim kuantitas, pematuhan maksim kualitas, pematuhan maksim relevansi (hubungan), dan pematuhan maksim cara (pelaksanaan). Pematuhan prinsip kerja sama yang terjadi dalam proses jual beli barang di pasar tradisional Surakarta didominasi oleh pematuhan terhadap maksim kuantitas, hal tersebut menunjukan bahwa tuturan singkat, jelas dan teratur. Pelanggaran prinsip kerja sama dalam proses jual beli barang di pasar tradisional Surakarta meliputi pelanggaran maksim kuantitas, pelanggaran maksim relevansi (hubungan), dan pelanggaran maksim cara (pelaksanaan). Pelanggaran prinsip kerja sama yang terjadi dalam proses jual beli barang di pasar tradisional Surakarta didominasi oleh pelanggaran terhadap maksim kuantitas, hal ini terjadi karena cara bertutur yang tidak secara langsung dan berkepanjangan. Pelanggaran prinsip kerja sama yang terdapat dalam proses jual beli barang di pasar tradisional Surakarta, disebabkan karena penutur bermaksud menunjukkan kesopanan dalam bertutur supaya tidak menyinggung lawan tuturnya.

Peneliti berharap para pemerhati bahasa dapat menggunakan hasil penelitian ini sebagai bahan acuan untuk meneliti kajian pragmatik secara lebih mendalam baik bersifat pengulangan maupun perluasan dari sudut pandang yang lain, dan semoga ada 
di waktu yang akan datang ada pembahasan mengenai tindak tutur di pasar tradisional Surakarta secara lebih mendalam dan berkualitas demi pengetahuan mengenai penerapan berbagai jenis kajian dalam analisis tindak tutur.

\section{DAFTAR PUSTAKA}

Asim Gunarwan. 1992. Persepsi Kesantunan Direktif di dalam Bahasa Indonesia di Antara Beberapa Kelompok Etnik di Jakarta dalam PELLBA 5. Penyunting: Bambang Kaswanti Purwo. Jakarta: Lembaga Bahasa Unika Atma Jaya. (179205)

1994. Kesantunan Negatif di Kalangan Dwibahasawan IndonesiaJawa di Jakarta: Kajian Sosiopragmatik dalam PELLBA 7. Penyunting: Bambang Kaswanti Purwo. Jakarta: Lembaga Bahasa Unika Atma Jaya. (hlm. 81-111)

2007. Implikatur dan Kesantunan Berbahasa: Beberapa Tilikan dari Sandiwara Ludruk dalam PELLBA 18. Penyunting: Yassir Nasanius. Jakarta: Lembaga Bahasa Unika Atma Jaya. (hlm. 85-118)

Austin, J. L. 1962. How to Do Things with Words. New York: Oxford University Press.

Grice, H.P. 1975. "Logic and Conversation" The Philosophy of Language Third Edition. New York: Oxford University Press.

Kreidler, Charles.W. 1998. Introducing English Semantics. London: Routledge.

Leech, Geoffrey. 1993. Prinsip-Prinsip Pragmatik (edisi terjemahan oleh M. D. D. Oka). Jakarta: UI Press.

Levinson, Stephen. C. 1983. Pragmatics. New York: Cambridge University Press.

Searle, J. R. 1974. Speech Acts An Essay in The Philosophy of Language. Cambridge: Cambridge University Press.

1979. Expression and Meaning: Studies in the Theory of Speech Acts. Cambridge: Cambridge University Press.

1996. "A Taxonomy of Illocutionary Acts" dalam A.P. Martinich (ed). The Philosophy of Language (third edition). New York: Oxford University Press. Hlm.142-149.

Thomas, Jenny. 1995. Meaning in Interaction: an Introduction to Pragmatics. London and New York: Longman. 